\title{
Agriculture, Agronomy, and Political Economy: Some Missing Links
}

\author{
Lluis Argemí
}

The founding years of political economy coincided with the birth and the golden age of modern agronomy. In the century that separated Jethro Tull from Justus Liebig and Jean-Baptiste Boussingault-after whom agronomy became applied chemistry-political economy underwent fundamental changes, for this was also the period that separated Richard Cantillon from John Stuart Mill—in short, almost the entire period of the development of the classical school of political economy.

This parallelism has not received the attention it deserves. Recent appraisals have included science as a factor in the making of political economy (Mirowski 1989) or have sought to link the two fields (Schabas 1992), but few studies consider the applied sciences and their techniques or, to use Mill's more precise definition applied to agronomy, their arts. Perhaps one reason is that agronomy is difficult to place: it is not exactly science, nor is it economics; it is, as one commentator has described it, "between reasoned practice and effective science" (Sigaut 1998, 197). And although some historians of science have analyzed agronomy in relation to certain sciences such as botany or medicine, no general vision

Correspondence may be addressed to Lluis Argemí, Departament de Història I Institucions Econòmiques, Universitat de Barcelona, 690 Diagonal, 08034 Barcelona, Spain. I must thank Jose Luis Cardoso, Philippe Steiner, Cosimo Perrotta, Vitantonio Gioia, and the anonymous referees for their comments on previous versions of this article. If it is well written, as one referee said, then this is thanks to Michael Maudsley, who helped me with the translation. I must thank especially Ernest Lluch, whose tragic murder made it impossible for him to read the final version of this essay.

History of Political Economy 34:2 @ 2002 by Duke University Press. 
of agronomy is given in these accounts, forgetting that many important authors, from Carolus Linnaeus to Gregor Mendel, had agronomic interests at the outset of their research. For their part, most historians of economic thought are reluctant to include agronomy as part of their discipline. ${ }^{1}$

This neglect is all the more striking since several studies link the birth of classical political economy with agrarian capitalism. One of those studies states that "classical political economy ... represents a social and economic theory of agrarian capitalism," derived from what Marx called "primitive accumulation" (McNally 1988, 12, 12 n). The same idea appears in a book that "offers a different interpretation of classical political economy, demonstrating that this school of thought supported the process of primitive accumulation" (Perelman 1984, 7), an accumulation that included the technical and social transformation of agriculture. Agrarian capitalism included a new social framework, many aspects of which were created in England by the enclosure movement, but it included new agronomic techniques too, techniques whose importance has been underappreciated in the studies in question. The social and political aspects of this economic structure have been analyzed elsewhere, but the agronomic techniques, and their relevance, have generally been ignored.

Indeed, agronomy has been largely overlooked in the history of political economy, just as the emergence of new industrial techniques (e.g., the substitution of steam power by electricity, the replacement of spinning jennies, or Sir William Siemens's discoveries) are generally passed over in the history of economic thought. In both cases, it is the interpretation of the economic results of these new techniques that has exercised economists or historians of economic thought—not the techniques themselves, or the relation between the two. But agronomy is rather more than a technique, or a body of techniques: as we stated above, it is an art, in the sense in which Mill used the term. In the first place, agronomy involves not only crop techniques, but the arts of economic management. In the German case, agronomy was included in the cameral sciences, which also embraced political economy as part of cameralism. Furthermore, agronomic practice needs to take account of the economic environment in which it acts. Its relationship with political economy was much closer than that between the new science and techniques

1. See the minisymposium on the history of economics and the history of science in the spring 1992 issue of HOPE. 
in other fields; one famous eighteenth-century dictionary even defined an agronomist as someone who wrote on subjects of political economy (Rozier 1787, entry for agronomie). So the importance of agronomy in eighteenth- and early-nineteenth-century economy should not be forgotten. A. Soboul, G. Lemarchand, and M. Fogel $(1977,240)$ state that three forces paved the way for modernization: physiocracy, cameralism, and the new agronomy. As agronomy was a part of the cameral sciences, and was an important complement of physiocracy, in the three forces agronomic techniques played an important role. Philippe Steiner (1998, 1318) has studied the definitions, in each of the three forces, of the science that was to become political economy. Most agronomists had specific ideas on economic matters: not only ideas relating to farm size or tenure systems, two of the main components of their systems/models, but also ideas about free trade, which they generally defended as much as political economists did. Agronomist authors should be considered, in relation to political economy, in the same way we consider "industrial" authors like Charles Babbage and Andrew Ure.

Agronomists, then, have been largely neglected, although there are some exceptions. Joseph Schumpeter $(1954,156)$ excluded agronomic literature from his History of the period up to 1790 "with misgivings"; in his view, "this literature contributed considerably to the formation of some of the habits of thought that are more characteristic of modern economics." As with so many other things that he planned not to consider, Schumpeter finally provides extremely useful information about agronomic literature. The only real exception is Keith Tribe (1978), who considered some of the most important agronomic texts of the sixteenth, seventeenth, and eighteenth centuries as an important element in the formation of economic thought, or, to use the author's term, economic discourse. On the other side, some historians of agronomy, such as F. Dagognet $(1973,9)$, link it with political economy (for Dagognet, agronomy opened the door to political economy); and F. Sigaut (1995, 205) has pointed to the moral aspects of a scientific theory. J. Nõu (1967) deals with a subject, agricultural economics, that is between the two fields, and he highlights a number of the links between them. Fortunately, we also have André Bourde's excellent study (1967), although it is limited to a particular area and time.

The object of this article is to consider some of the habits of thought of agronomists who contributed to political economy, formed by some conceptual tools and models that agronomy used and that political 
economy may have appropriated during the golden age of the two disciplines. To this end we will analyze the original works of agronomists not in the light of their bearing on the history of agronomy, but as a source for the history of political economy, a source that has been largely neglected to date.

Four aspects will be dealt with in detail: first, the origin of the surplus concept, notably in its produit net form, proposed by the physiocrats; second, the law of decreasing returns, as first put forward (in its intensive form) by Anne-Robert-Jacques Turgot; third, the specific form that technical change adopted in agriculture, as seen by David Ricardo and Johann Heinrich von Thünen. Finally, some agrarian models of the economy, from Cantillon to von Thünen, including François Quesnay's royaume agricole and Ricardo's corn model, will be analyzed with particular emphasis on their agronomic components.

As can be seen, the physiocrats were active participants in most of these relationships. The physiocrats were political economists who exemplified the link between agronomy and political economy in a fully developed form. But it should be said that this relation reached its highest point with Arthur Young, von Thünen, and Albrecht Thaer (Nõu 1967), who compared the different systems of agronomy in terms of their economic results. These agronomic systems, and the agricultural realities that these theorists sought to formalize, must be analyzed first.

\section{Agriculture and the New Agronomy:}

\section{The Technical Basis of the Agricultural Revolution}

According to G. H. Slicher van Bath $(1974,234)$, many types of farming methods existed in eighteenth-century Europe. Leaving aside temporal crops, infield-outfield systems, and other ancient methods, the standard system was the three-field system in the north and the two-field system, of Roman origin, in the south: both short-fallow systems. In some parts of Spain, the three-field system was applied on a one-crop basis (wheat, stubble to graze, fallow), a method that was even less intensive than the two-field system. The three-field system probably evolved during Carolingian times as a synthesis between the northern two-field system, with a spring cereal, and the southern two-field system, with a winter cereal. Even calendars were adapted to the seasonal labors of this system (White 1962, 69-70). 
But traditional agriculture, the three-field system, had serious limitations. The level of productivity obtained was excessively dependent on climatic conditions, and bad harvests and famines were all too common. The surplus created to maintain the rest of the economy was not only small, but was liable to vanish suddenly. In these conditions, agricultural intensification was a social necessity and was advocated by both economists and agronomists. The techniques known at the time did not allow direct intensification, a simple substitution of the fallow year by another cereal crop, for this would have prevented manuring. But soon, peasants - the best practical agronomists - discovered indirect methods. Regions dedicated to cattle or to some form of animal production (e.g., horses) in general were not subject to the irregularities of cereal production, even though they were generally considered to have poor land. Some form of husbandry was introduced in the areas that were mainly devoted to cereal production, in a process of intensification (Braudel 1979, chap. 1).

From this perspective, and in very simple terms, we can define three different forms of agricultural intensification in the sixteenth, seventeenth, and eighteenth centuries, all of which reduced or eliminated fallow and some of which included fodder crops: convertible husbandry; the Koppel systems, to use the German term for the most important of them; and the Norfolk and other Continental intensive systems, whose basic and original example on the Continent was that of Flanders. In some limited cases, intensification was obtained by the use of fallow to grow pastures, either natural or artificial ([Mallet] 1780, 22-26), but maintaining the basic elements of the three-field system. As a special case, the expanding vineyard in the Mediterranean also constituted a system of agricultural intensification that allowed for a much greater accumulation of capital.

Both the intensive systems of husbandry and wine production derived from the increase in demand that arose from an increase in population (Abel 1980, 201-3), but the increased demand also affected goods other than corn: sheep in one case, and alcohols in the other. One of the reasons for adopting convertible husbandry had been the rise in wool prices due to the increase in demand from the Flemish mills, a movement that was one of the causes of the enclosure movement, if not in the initial Tudor movements, at least during the eighteenth century. Enclosure could take several forms, but all of them involved turning lands to pasture in private hands (Slicher van Bath 1974, 242-46). This is why in some of the 
agronomists' explanations of this system the basic livestock was sheep, causing Thomas Moore, Jean-Jacques Rousseau, and Gaspar Melchor de Jovellanos to complain that sheep were driving out men. But Spain faced a different problem, in the form of the rights of the mesta, the union of the great sheep owners.

The increase in the area dedicated to vineyards came also from the demand side. The increasing demand for alcohol in northern Europe affected a wide area, from Catalonia to northern Italy, and in the former case it represented an important impetus for a process of capital accumulation that paved the way for the industrial revolution. In general, the surplus created by wine-growing regions was much greater than that created by wheat-growing regions.

Convertible husbandry did not replace the short fallow systems as the basis for the production of the basic crop, wheat; it merely reduced the surface given over to the two- or three-field systems and left the rest for ley pasture to raise livestock, mainly sheep. After a number of years, the two parts changed; normally, as the pasture part had been manured by the livestock, the fallow year of a cycle could be bypassed. The term convertible husbandry (also known as "up and down husbandry") is sometimes used to describe all systems incorporating corn cultivation and pastures or fodder crops, but here we limit its use to the combination of corn production and natural pastures, because the natural pastures were later substituted by artificial ones, characteristic of both the Koppel systems and the intensive, Norfolk, or Flanders-type systems.

An evolved form of convertible husbandry was the Koppel-type systems, in which natural pasture was integrated into crop rotation and was sometimes replaced by artificial pasture (ray-grass, sainfoin or esparcet, and luzerne or alfalfa), and the systems evolved from a rotation between barley and grass. The most developed form was the one in use in northern Germany in the eighteenth and early nineteenth centuries, and even though Thaer ([1809] 1831) was a defender of the English systems, he also saw many advantages in the German model.

In the intensive systems, of which the best known is the Norfolk system, the fallow year is substituted by a fodder crop, and an artificial pasture is added between courses of cereals. This provides a root crop such as turnips (to maintain the soil free of unwanted plants) and a leguminous crop (to increase the nitrogen content of the soil). At that time the scientific principles involved were not well known, but practice had shown increased productivity: so much so, in fact, that the significance 
of leguminous crops has been compared to that of the steam engine in industry (Chorley 1981).

Similar practices were adopted outside Norfolk. On the Atlantic coast, south of Brittany, maize was becoming a central crop, and geese the principal livestock; in Flanders, pigs and potatoes formed a staple; in mountainous regions, horses and natural pastures were the standard combination. And none of these regions had a problem with food supply, which suggests that agronomists, for whom corn was the first objective, were misled (Mulliez 1979). After the revolution in France, supplies of Haitian sugar fell, and beets were encouraged by Napoleonic ministers such as the agronomists Jean Antoine Chaptal and François de Neufchâteau, and introduced in the crop rotation. The new crop provided sugar and fodder for livestock. All these systems were based on the same agronomic principles, and some of the systems from outside England provided the Norfolk system with its basic components: Hannover provided turnips (as well as a new dynasty), the Mediterranean area provided alfalfa, esparcet, or sainfoin, etc. (Ambrosoli 1992, chap. 3).

Vineyards were a completely different system, and indeed a different culture in the wider sense of that word, but their expansion during the eighteenth century may have been responsible for an important development - the fact that other systems adopted a number of techniques used with this crop, especially row cultivation: Tull probably got this idea in France, near Sète (Marshall 1929).

It is possible to consider these systems as a historical sequence. In the three-field system, a part was reserved for pasture; later, fallow was also partially replaced by pasture, at least in some cycles; still later, some fodder crops were introduced, thus achieving a system without fallow. But as a matter of fact, different zones adopted different forms of intensification, and the three ways mentioned may be considered independent forms of agricultural modernization. The different stages can be considered in groups, based on a few standard rotations. This procedure was also applied by botanists such as Augustin de Candolle (1832, 149395), agronomists such as Thaer ([1809] 1831) and von Thünen ([1826] 1851), and by economists such as Wilhelm Roscher ([1859] 1876, 641). In modern times, the most standard classification of systems of cultivation of this type was done by Esther Boserup (1967, chap. 1). Ancient long fallow systems, short fallow ones (three-field or two-field), convertible systems (including Koppel), and intensive (Norfolk, and Flanders or Belgian) are the common denominators of these groups. 
We tend to think that agronomists were at the forefront of the agronomic change implied by this evolution, but in fact the evolution of agricultural practices had already begun; it was the agronomists who formalized them. In any case, any history of agronomy must mark the starting point of this evolution with a chapter dedicated to Jethro Tull. What is curious about Tull is that he sought to propose an alternative to the intensive Norfolk-type systems ([1731] 1751). He was against traditional (three-field) agriculture and also against the new agronomy. His ideas were probably only implemented in limited cases, since his system was mainly theoretical; it did not include crop rotation, and in fact was a direct attack on the intensive practices of the systems outlined above. Tull maintained that it was possible to grow each of the components of the Norfolk system separately, without fallow, and increase productivity at the same time. To do so, the different crops had to be cultivated in rows and had to be constantly "hoed" by horses to eliminate unwanted plants. But his system may be more usefully considered as one in which wheat, turnips, and sainfoin can be cultivated side by side, without crop rotation. The claim that it eliminated fallow is in fact false, for it included fallow in the uncultivated areas between the wheat or turnip lines or bands (Marshall 1929). At the same time, fodder crops, normally roots, were the best way to maintain land free of weeds.

The different practical systems had their apostles, agronomists and/or economists who advocated their expansion after formalizing its practices. Many books can be taken to represent traditional agriculture, but the book by Charles Estienne and Jean Liebaut (1586) is perhaps the most appropriate example, as Quesnay used it to learn to read. The most important of the advocates of simple convertible husbandry, but with artificial pastures, was Simon Philibert de La Salle d'Etang (1764; see also Bourde 1967, 386-91). Arthur Young was the great propagandist of the Norfolk system, and British hegemony, together with Young's fame, led to the identification of the Norfolk system with intensive agriculture. But the other European systems also had their advocates, who unfortunately did not reach as wide an audience as Young. We will mention a few here. Henri Louis Duhamel de Monceau (1750) was the father of intensification in France; he discussed Tull's ideas, but presented a new system in another work (Duhamel [1762] 1813); the Flemish system found a spokesman in Robert Xavier Mallet (1780); vineyards had M. de Maupin (1780) and M. Bidet ([1759] 1788), one of Duhamel's disciples, as theoreticians; the type of agriculture that the French Revolution 
and its aftermath had created had a good representative in Jean Antoine Chaptal ([1823] 1829), one of the main instigators of the introduction of beets in the rotation of crops; and the intensive German systems were defended by Thaer ([1809] 1831) and by von Thünen ([1826] 1851). Philippo Re (1802) was the great agronomist of the pianura padana, the Italian region where some of the intensive practices had originated. Candolle $(1832,1510)$, an eminent botanist who in fact created the discipline of plant geography, noted that a system similar to the Norfolk one had been in use in a region in northern France, in the Morsine valley in Chablais, for many years, and that it had developed autonomously.

In any case, to limit the agricultural revolution to Norfolk, to Tull, or to turnips (as did some eighteenth- and nineteenth-century agronomists and political economists as well as historians) is probably misleading, especially if one considers Europe as a whole. Tull was against crop rotation, the basis of the new agriculture, and many contemporary agronomists were much more realist in their criticisms than Tull. In many places the agrarian revolution was completed with crops and rotations that were not those used in Norfolk. The basic difference was the extent to which the new techniques, the new crops, and Tull's fame spread. In England and in the western European regions close to the channel their influence was wider, just as before 1830 the industrial revolution had expanded further in England and in what was to become Belgium than in other parts of the Continent. But the agricultural revolution reached different places under a variety of forms, and agronomists described the changes faithfully.

Most of the agronomists had a scientific background. Up to a certain point, agronomy had developed as an offshoot of medicine, in search of medicinal plants. Estienne and Liebaut, Mallet, and even Chaptal were doctors. Tull based his proposals on John Evelyn's ideas of natural philosophy (Evelyn 1706). In spite of the possible differences in their scientific vision, all maintained a form of the dominant vitalist theory by which living beings needed organic matter for nutrition. In the case of vegetables, this led to the humus theory, clearly expounded by Johann Gottschalk Wallerius (1774) for the first time, but present in almost all the authors mentioned, and most specifically in Thaer. According to that vision, manure was the only possible nutrition for vegetables, meaning that livestock was a necessary complement of agriculture due not to its products, but to its by-products. As corn was the ultimate objective, other crops were seen as forced limitations on corn production. No clear idea 
of the role of nitrogen, or of the role of root crops to destroy unwanted plants, had yet evolved. New agronomy was born of this ignorance, but also of the practices that overcame it.

At the same time, most of them expected tangible benefits from the application of their sciences, and increasing agricultural production was one of the most important means of increasing the wealth of the country (Spary 1996, 179). In some cases, their contribution had a political origin: Duhamel was responsible for French naval affairs, so he promoted the cultivation of woods, hemp, and linen (Marcandier 1758), useful for shipbuilding. Mallet, too, introduced hemp and linen and certain crops, believing, as Linnaeus did, that some tropical crops should be introduced in Europe (Spary 1999, 290). And as the economy was seen as a system that could be reduced to scientific principles, the application of sciences to political economy, via agronomic techniques, would be their contribution to the improvement of mankind (Schaffer 1999, 134-43). One well-known agronomic treatise had the title L'ami des laboreurs (Rose 1769), according to the fashion created by the Marquis de Mirabeau's famous book L'ami des hommes (1756).

Agronomists, in general, also advocated a certain institutional framework for these new techniques. New crop rotations needed large areas and long periods of time and, in economic terms, capital. So their ideas are linked to large farms, long leases to provide security, and entrepreneurs, but in many cases, their hero was the tenant owner, the gentleman farmer, le gentilhomme cultivateur. They also had clear ideas on other economic subjects, for instance, population, given that their main objective was to feed a population that was fast increasing. There were a few exceptions, such as Mallet (1780), who defended small farms simply because his main concern was to increase population, and in his view small farms were the best way to achieve this; and some others who did not completely accept free trade in corn. Most agronomists also defended free trade in corn, both internally and externally, and the standard position they maintained is reflected in Mallet's defense of corn exports (1780, 187-89) or in La Salle's views (1762, 247-312). Some authors such as Duhamel (1764) even made specific contributions to this field.

But both techniques and institutional framework were seen as a unit by almost all these agronomists, and Arthur Young's writings ([1773] 1967) are the best demonstration of this view. It may be said that Young was more an economist than an agronomist, but he maintained relations with an important agronomist, John Sinclair; Sinclair's book (1821) 
bears resemblances to Young's last proposal. Indeed, Young, who had not written a treatise on agronomy, wanted to do so (Nõu 1967, 89). This relation may be important because Sinclair was one of the last exponents of classical agronomy in England, as was Thaer in Germany. Both were translated into French by a leading French agronomist, Christophe Mathieu de Dombasle.

Parallel with this line inside agronomy, another was to develop. Following the principles of Antoine-Laurent Lavoisier, his heir both as professor of chemistry and state controller of powder production, Chaptal ([1823] 1829) advanced toward the identification of agronomy with practical chemistry. He was the first to propose that nitrogen was taken from the air, an idea that Théodore de Saussure (1804) was developing at that time and that reached its highpoint in the two last researchers in this line, Jean-Baptiste Boussingault (1851) and Justus Liebig (1880). Although their ideas on nitrogen were different (Boussingault did not reduce the fertilizing power of manure to the chemical components, as Liebig did), both contributed to the destruction of the humus theory and paved the way for a new type of agriculture and, of course, a new type of agronomy. Their idea was an "agricultural industry," an idea created by John-Baptiste Say ([1803] 1972) and adopted by Chaptal, who titled the relevant chapter of his main work "De l'industrie agricole" (Chaptal [1819] 1993). It may be reduced to the idea that "plants" in a botanical sense were also "plants" in an industrial sense, for they took mineral inputs and transformed them into consumer outputs. In the case of Liebig (n.d., 162), it is curious that he mentioned Mill as the author of the law of decreasing returns in economic terms and let commentators say that he had provided a scientific proof for it with his law of the minimums (Usher 1923), but this idea was refuted by others (Roscher [1859] 1876).

But both Liebig and Boussingault also had a conservationist vision of agricultural practice, similar to that held by earlier agronomists and scientists, from Linnaeus ([1758] 1972) to Lavoisier, for Linnaeus could have provided the idea of economic science that covered the practices of agronomists (Steiner 1998, 13). In this respect, Liebig and Boussingault thought that as many nutrients should be returned to the land as possible and in the same place where they had been extracted. This is why, in both cases, small-farm agriculture was better in terms of conservation. Unfortunately, they have not been included in the history of economic thought, but they have a place in the history of heterodox economic-ecological 
thought, as do the other authors included in this section (Martínez Alier 1984).

Political economists also defended specific ideas on subjects that were common to them and agronomists, such as farm size and tenancy systems, and, of course, on the corn trade. As in the case of agronomists, and since the physiocrats, large farms (la grande culture) and long leases were the norm. But some exceptions appear too. In his letters to the Marquis of Longo, Mirabeau accepted small farms in the form of the Italian mezzadria as a good system; Adam Smith ([1776] 1976, 383-85, 832), in his discussion of primogeniture and when he advocates the direct activity of landlords, seems to have preferred medium-sized farms that could be controlled by the owner. The situation changed after the French Revolution: during the nineteenth century small tenancies were transformed into small properties (Dewey 1974), and a process of intensification began that led to a type of "agricultural revolution" in France (Newell 1973) based on beets and not on turnips. Simonde de Sismondi's ideas express this view (Sismondi [1819] 1971, bk. 3, chap. 1, 172, 186), and Say ([1803] 1972) also subscribed to this moderate idea. Somewhat later, Mill ([1848] 1965, bk. 2, chap. 6) saw the advantages of a different agrarian structure, based on small proprietors, which was capitalist too, but solved certain social and economic problems.

The final step in this evolution came with the new fertilizing techniques (using guano and bones, and subsequently artificial and chemical fertilizers), for these techniques did not need large farms or leases for long periods of time, and Liebig, who advocated small farms, was the last link in this line. For Liebig, small farms helped to keep nutrients in the soil, for their production did not go far away to be consumed and lost. He even praised the Chinese idea of using manure from the cities to fertilize the surrounding areas (Liebig 1880, 218-26). But the most important discovery was that rotation was no longer necessary: if nutrients were provided, any crop could be repeated again and again. Agronomy as the art of crop rotation almost died out, for its secrets had been revealed: from that point on, practical chemistry was the basis for agricultural production. All that was required was the replacement of the nutrients. Large farms were no longer an objective, although they still were a subject of discussion (Levy 1966). 


\section{Economic Tools}

The classical economists saw agriculture as a special sector with specific characteristics of its own. Each of these economic characteristics was influenced to some extent by agronomic ideas or observations. Probably, economists were able to obtain more general conclusions than agronomists, or, in other words, they gave macroeconomic significance to microeconomic definitions; nonetheless, some agronomists also grasped macroeconomic ideas.

In the history of economic thought, the first basic difference is that agriculture is the only productive sector, a statement first made clearly by Quesnay and the physiocrats. In Quesnay's ideal case, the produit net was paid as the fermage, or rent of land, and may be considered as the origin of the study of this concept. Smith corrected this view when he stated that capitals in agriculture were more productive than in the other sectors (Smith [1776] 1976), for they allowed the payment of rent, profits, and salaries. The extra production was paid as rent, as in Quesnay's case. The origin of that extra production lay in the fact that the demand for some products of land was always enough to afford a higher price (Smith [1776] 1976, 162).

This concept of surplus had agrarian origins. The concept first appears in Sir William Petty, although he simply uses a model of corn production, with no consideration of the technical means used (Aspromourgos 1996). It is known that Petty was interested in the new agrarian techniques (Ambrosoli 1992, 321, 330), as was Locke (Wood 1984, 27), although little can be concluded about this relation, except a confirmation of D. McNally's thesis $(1988,12)$ that political economy represents the social and economic theory of agrarian capitalism.

But the concept of surplus was defined in a precise form by Quesnay and the physiocrats, by the term produit net. This concept had its origin in a work of agronomy. J. C. Perrot $(1992,219)$ states that the term produit net appears in Duhamel de Monceau's discussions of Tull's system. The context is as follows:

The part sown in the ordinary way, and for which 63 pounds 4 ounces 2 gros of seed had been used, gave twelve franchards of fine wheat, weighing 480 pounds, the tithe and the rent having been paid; the same should be understood of the same portions of field, without my having to repeat it. So the produit net amounts to 417 pounds. (Duhamel 1750, 5:158) 
The statement is made by one of Duhamel's correspondents, M. de la Croix, and reports a comparison of the new and the old systems. As can be seen, produit net refers to physical surplus — harvest minus seed — but the term payés, paid, points to an economic measure, a value measure.

Using this concept as their starting point, the physiocrats went on to obtain an economic concept. According to Pierre Du Pont de Nemours ([1768] 1992), one of the major discoveries of Quesnay's article Grains was the presentation of "the distinction between total product and net product." In Quesnay's work, the term produit net appears for the first time in Grains, where the analysis of the average yields of grain production in France, after taking into account the average costs, revealed that "the total 87 livres of the five years, costs deducted, divided in five years amount to 171.8 s. net product" (François Quesnay, 1958, 462). Apart from the quantitative difference due to the use of different areas, the concepts are the same and are expressed in the same units in both cases, so it cannot be said that they were quantity measures for Duhamel and value measures for Quesnay. If inputs and outputs have the same quality, a value measure is not necessary.

Later, in the article Impôts, produit net is defined in a precise form: "The wealth that constitutes the nation's revenues is made up by the products that, after subtracting all expenses, form the profits obtained from the land" (François Quesnay, 1958, 582).

However, this macroeconomic concept had a microeconomic basis expressed elsewhere: "So you see that one must divide the farmer's reproduction in two parts: the part that is for his own subsistence, and the part that exceeds this level of subsistence.... For example, supposing that reproduction amounts to twenty, the farmer's cost ten and the excess ten, if the cost can be kept down to eight, then the excess will be twelve" (François Quesnay, 1958, 469).

Produit net and surplus (excédent) are identified in this way, and Charles de Butré (1781) equated produit net with revenue net, as did Quesnay in the tableau économique.

The term was used from then on in agricultural accounting more than in political economy, once the physiocrats had lost their position of prominence. In La Salle's main work (La Salle 1764), the results of different agricultural exploitations are presented using this concept, and a standard result of 500 septiers (quantity measure) in a farm of $300 \mathrm{ar}$ pents (a standard size also used by Quesnay as an example of la grande culture) gives only 100 septiers produit net after paying 100 for seeds, 
100 for cultivation expenditures, 100 for the salaries involved, and 100 for taxes, corvées, community expenses, etc. (La Salle 1764, 18-19). The results are presented in quantity, but the inclusion of expenses suggests an economic measurement, for everything is measured in the uniform product, both input and output. Furthermore, on some occasions, produit net and revenue are identified (La Salle 1764, 23-24).

A second difference lies in the fact that agriculture offers decreasing returns, while manufacture or industry offers increasing returns due to its incorporation of the division of labor. The basic agricultural factor of production-land - was scarce, or relatively scarce, considering particular variables such as fertility and distance to markets. From J. Anderson ([1777] 1966) and Turgot ([1767] 1997), the idea passed on to Ricardo (1951-73, vol. 3 [Essay on Profits]), who based the origin of rent on it, discarding Smith's idea (mentioned above) of agriculture's extra productivity. Later, von Thünen ([1826] 1851) included the distance variable beside the quality variable. As a final step, the principle of decreasing returns was later generalized to all the factors of production, not only land. As such, it is the cornerstone of marginal analysis.

Several studies have sought to find early defenders of this principle, before its incorporation into political economy. However, the law has two versions: the extensive margin and the intensive margin. As far as the law of extensive margin is concerned, after J. R. McCulloch and Schumpeter, there is little doubt that Anderson is the first clear exponent of the law (Schumpeter 1954, 262-63; Anderson [1777] 1966), and he linked it to the origin of rent. But this is the easy version of the law; indeed, economists from Richard Jones to Henry Carey have tried to reject it on historical grounds.

The precursors of the second version-the intensive-margin version-have received less attention. It appears that a clear exposition of the law appeared for the first time in Turgot's writings. In the Observations sur la mémoire de Saint-Peravy, the law is clearly explained in this context:

If Tull's system has any truth, one may gain in production by economizing greatly in seed; then the avances will be reduced, and production will increase. Production requires avances, but equal avances in lands of unequal fertility give highly different productions, and this suffices to show that productions cannot be proportional to the advances; they are not placed in the same land, and one can never 
assume that double advances will give a double product. (Turgot [1767] 1997, 253)

As can be seen, this is a clear exposition of both versions of the law, and, even if Turgot was not their inventor, it may be said that he was the first author to make a clear (and brief) exposition of both, and especially of the intensive-margin version.

The important point here is the reference to Tull's system, which Turgot probably knew of through Duhamel. In Duhamel's exposition and criticism of Tull's system, at several moments the emphasis is placed on this saving: "One consumes much less seed than usual following $\mathbf{M}$. Tull's method. . . . But as it is of little importance whether there is a little more or a little less seed in a field, we will achieve sufficient precision if we use a new seed drill, and will save considerable quantities of seed" (Duhamel 1750, 1:192).

Leaving aside the agronomic corrections added by Duhamel, Turgot's interpretation of Tull is correct in one aspect: the system needs more labor input, and the returns are not proportional to it. The observations of Turgot and Duhamel had a focal point: the use of Tull's machine allowed the saving of seed. So it may seem a case of technical innovation, of the land-saving type.

The law of decreasing returns received further support from agronomy some years later. It was said that Liebig's discoveries were proof of the law, especially his law of minimums. Liebig reduced agricultural practice to applied chemistry, and the basic objective of this practice was to renew the chemical contents of the soil once a crop had taken what it needed for growth. But the nutrients had to be in specific proportion to the crop needed; without this balance, adequate nutrition will be lacking: "No single element of the indispensable minerals is superior to any other, but all have equal value for the life of the plant. Therefore, if one element is missing from the soil, the others cannot produce a properly developed plant until the missing element has been supplied" (Liebig $1880,6)$. This law was to be known later as Mitcherlich's law of the minimum, but Liebig was the real author (Martínez Alier 1984, 191). So for Liebig, decreasing returns at the intensive margin appeared when capital, in the form of fertilizers, was applied to land. It was not until after Liebig, with the neoclassical school, that the law was applied to any productive activity, not only to agriculture. 
A third difference, which began with Adam Smith (1990, 16), lies in the fact that division of labor cannot go very far in agriculture; clearly, the seasonal nature of agriculture limits this possibility. Later, Ricardo (1951-73, 1:80) noted the difference between land-saving and laborsaving innovations in agriculture. Thomas Malthus ([1803] 1989, 13) did not use this principle totally, for he appealed to common intuition, but he included diminishing returns as the limiting factor in the productions of the earth in the third edition of his book, and it thus became a part of his population principle. In modern times, technical change in agricultureas distinct from the standard technical change in industry-has been studied by Nicholas Georgescu-Roegen (1969) and J. Brewster (1950). Y. Hayami and V. Ruttan (1971) studied the differences in the development of countries according to the scarcity of the two factors, land and labor. Boserup (1967) added an important consideration: in agriculture there is a specific technical change, not considered by Ricardo, a technical change that, although land-saving, is labor-using. This is precisely the type of technical change that had allowed avoidance of the Malthusian trap up to the application of Liebig's discoveries, and according to Boserup, it was induced by population pressure. Techniques of this type have been central features of the two great agricultural revolutions in history. M. N. Cohen (1978) has studied the origin of the neolithic revolution. At a microeconomic level, P. Timmer (1969) has shown how the introduction of turnips was a labor-using technique, and J. M. Sumpsi (1978) has shown how the change from a Spanish three-field system to a two-field system was not a rational choice, because of the extra labor costs involved. The new agronomic techniques would be extremely expensive if applied only by a few people, and profitable if applied by all at once; this would cause a change in economic conditions (Nell 1984). Agronomists tended to adopt them, while economists were reluctant to do so; in the long run, it was the vision of the agronomists that triumphed.

The reason for the larger labor costs in a change to new agronomic systems is obvious, if taken in its agronomic aspects, but not so in its economic aspects. If we measure labor input in man-hours, rather than manyears, it meant that preexisting workers worked more intensively than before; with the old agriculture, they had been idle during parts of the year (Boserup 1967). The results were obvious to certain agronomists, when comparing different agronomic systems. Thaer saw clearly the effect in economic terms of a change from one system to another: the extra 
circulating capital involved in the intensification process was added and improved the qualities of the land-capital, so it was not possible to account for it as profits. This is why it seemed that there was a loss when passing from a poor system of cultivation to a good one, especially in depleted soils (Thaer [1809] 1831, 31).

Von Thünen ([1826] 1966, 157-58) also saw the point under discussion:

We saw that [if] the improved or the crop alternation system is adopted on a holding within the bounds of the three field system, it will in due course vanish without a trace.... As a country grows in wealth and population, more intensive cultivation becomes profitable; and if conditions have reached the stage where a higher farming system is viable, the efforts of the farmer who first introduces it will prove permanent. The new system will prosper on his own land, and slowly, but irresistibly, it will spread throughout the country to become the ruling system.

In this case, the results would be the same if no transport costs were involved.

Both Schumpeter $(1954,263)$ and Mark Blaug $(1985,70)$ say that there are no decreasing returns to technical change, and this is probably true in the long run. In the short run, Boserup's ideas suggest the opposite. Leaving aside the differences in outlook-or to use Schumpeter's term, vision-many problems facing agronomists and economists were the same, and some of the tools that the agronomists' habits of thought created influenced the work of economists. The combination of some of these tools formed the basis for some of the most important models of the economy, which were agrarian in origin.

\section{Agrarian Models: Cantillon, Quesnay, Ricardo, von Thünen}

An important difference between agriculture and industry as productive sectors is that inputs and outputs in agriculture are of the same quality and may be compared directly. This is the basis for the assertion that the rate of profit in agriculture determines the rate of profit in the other sectors, as Ricardo stated in his corn model and tried to maintain in his Principles (1951-73, vol. 1). Malthus ([1815] 1969, 3) took Ricardo's idea a step further, stating that one of the origins of rent in agriculture 
was that the necessary products of life (agricultural goods) created a demand in proportion to production. For him, the relation was not only qualitative but quantitative, so Say's law seemed to be a characteristic of agriculture, but we know that he thought it was not a characteristic of an economy as a whole.

Anyhow, this characteristic was the basis for one-sector models of the economy, defined as an agricultural economy. One-sector models of the economy have been commonplace in the history of economic thought and indeed occupied a position of importance at the birth of political economy as a discipline. In recent times, although models of this type have used specific sectors such as sectors producing putty transformed into clay, or steel that can become "leets" (an imaginary good used in modern growth models), the fact is that they may be theoretically sound but are difficult to imagine. Labor may be reproduced by many things, but putty, clay, steel, or leets are hardly good candidates as foodstuffs. Perhaps "the declining importance of agricultural land" (Schultz 1951) has led economists to look for alternatives to one-sector agrarian models, but the basic characteristics remain, in spite of their lack of relevance today. In the period under consideration, however, agriculture was still the most important sector.

Agriculture is the most representative sector of an economy, for in an ideal situation, its product is the basic consumption good and the basic circulating capital good. In the more sophisticated Ricardian models, agriculture is the producer of salary or basic goods. The differential characteristics defined above led agriculture to be considered as an economy in itself. So the initial models of the economy were models of an agricultural economy, in which agricultural techniques played an important role. At different moments, with different techniques prevailing, four political economists used stylized models in which agriculture was the only sector (common enough up until the mid-nineteenth century, since industry was still in its infancy and industrial activity accounted for only a small part of the economy as a whole), and furthermore introduced, in some way or another, agronomic techniques. This is the basic reason for putting together Cantillon, Quesnay, Ricardo, and von Thünen; but, to a certain extent, they also form a chain of thought in relation to political economy applied to agriculture.

The first model to consider is the famous closed-economy model described in chapters 14 and 15 of Cantillon's book. 
In general terms, these two chapters show that Cantillon defended a decentralized economy (when the landowner rents the different parts of his land to the previous supervisors) against a centralized one (as described in the statement above, with the supervisors acting as such) (Brewer 1992). A. Murphy $(1986,17)$ holds that this model reflects the author's experience of agrarian life in Ireland, while the other two parts of the Essai (international trade and monetary economics) reflect his experience as a banker in Paris and London.

But it is the use of the land that is of interest here. Cantillon ([1755] 1997, 34) supposes that part of it is dedicated to wheat for human consumption and another part for other uses, among which are the raising of oxen, sheep, and other animals.

The part dedicated to human consumption is cultivated with the threefield system: "Today Land in Europe yelds on the average six times what is sown, so that five times the seed remains for the consumption of the People. Land usually rests one year in three, producing wheat the first year and barley the second" (Cantillon [1755] 1964, 71).

The lost quantitative analysis was based on this assumption, as Cantillon ([1755] 1997, 39) clearly says.

Somewhat later, Cantillon discusses the effects of a change in the balance between the three-field system, dedicated to human consumption, and the area dedicated to pasture: if farmers devote greater areas to crops, then the amount of land available for pasture will be insufficient to meet the demand for wool.

In conclusion, his description is based on a country in which agriculture is organized around convertible husbandry, as the above statements suggest. And, as was the case, demand movements, via prices, affect the use of land (i.e., sheep or corn). The influence of the enclosure movement seems to be present.

The second model, Quesnay's royaume agricole, is a step forward in the same direction. It is sometimes said that Quesnay appropriated the agronomic ideas of Duhamel, Charles de Butré, or Henri Patullo ([1758] 1774), a physiocrat of secondary importance and also an agronomist of the modernizing group. But Quesnay mentions La Salle, apparently an opponent of the new systems, as often as he mentions Patullo, an apparent contradiction.

A second contradiction, even more important than the first, is that Quesnay describes the technical component of la grande culture, the modern system, as the three-field system, a method of cultivation that in 
eighteenth-century France could be described in many ways, but never as modern: its origins dated back to the ninth century, in Charlemagne's time. Although in Quesnay's ideas oxen or horses seem to be an important element in the difference, agricultural systems are linked to it.

Quesnay acquired his interest in agronomic matters in his youth through reading the classical work of Estienne and Liebaut (1586). At Versailles, he met an agronomist who also wrote some articles for the Encyclopédie (in particular, Fermiers, but from the point of view of rural economics, not political economy, as Quesnay did). After Quesnay had written the first articles in the Encyclopédie, Fermiers and Grains, two other agronomists, Butré and Patullo, became his disciples, and the school was formed. Patullo ([1758] 1774, 173-86) even included part of the article Hommes in his work, as a complement of the analysis of the economic results of his agronomic proposal. Quesnay asked Patullo to write a book on agronomic practices, but the latter answered that he needed more information. The plan was to collect information through a questionnaire, Questions intéressantes (written by Quesnay and a certain Marivelt, probably in fact Patullo or Butré) (Hecht 1958, 254-58). From then on Patullo appears in Quesnay's writings, but the main ideas of Quesnay's model are still based on the three-field system as against the two-field one. In the scientific aspects of agronomy, Quesnay's vision is linked to the theory of humus, a theory that would be developed in its most complete form by Thaer. The term humus appears in the Questions intéressantes as the basic component of soils (François Quesnay, 1958, $621)$.

In Quesnay's description of his model, as the article Grains shows (François Quesnay, 1958, 459-65), the ideal agricultural use of his royaume is that proposed by La Salle. This French agronomist defended a system of convertible husbandry, dedicating one-fourth of a farm in his first proposal (La Salle 1762), or one-eighth in another description (La Salle 1764), to artificial pastures. According to Quesnay, "The author of Prairies artificielles decides most judiciously that approximately the same number of arpents of artificial grasslands are required as there is land sown with wheat each year" (François Quesnay, 1958, 481).

The final result of this evolved convertible husbandry is an intensive system in which fallow appears every seven or eight years. In Grains, Quesnay uses La Salle's idea to calculate the product of his ideal royaume agricole of France, maintaining la grande culture and substituting la petite culture, or a part of it, by La Salle's system, a combination that 
is called la bonne culture (François Quesnay, 1958, 475-78). The final part of the article, Maximes du gouvernement économique, later became Extrait des économies royales de $M$. de Sully and was finally included in the tableau économique as the Maximes générales du gouvernement d'un royaume agricole. So the Maximes is one of the main physiocratic texts and was partially obtained from La Salle's ideas.

Later, in the Questions intéressantes (François Quesnay, 1958, 61928), Quesnay mentions Patullo in several notes, and La Salle no longer appears. In any case, the questions are now a description of principles, and when referring to la grande culture, no technical difference is added, and size and use of horses and oxen are still the main difference. In relation to the problem of la grande culture and la petite culture, La Salle continues the tradition represented by Quesnay (La Salle 1764, 13-14), but his emphasis is on the agronomic difference between the two systems (two- or three-field), while other authors such as Turgot stressed the capitalist differences of la grande culture, in his Mémoire au conseil sur la charge des impositions, la grande et la petite culture (in Turgot [1767] 1997).

According to G. Weulersse (1968, 345), Quesnay adopts La Salle's system in an attempt to intensify cultivation. As he also allows the introduction of some other crops such as turnips, albeit only marginally, the final result comes close to being an intensive system like the one defended by Patullo (Argemí 1994)

Quesnay's proposals may be seen as a model of economic development. In the eighteenth century there were a range of possible models: a commercial republic, along the lines of Venice in its heyday and which had evolved in Holland in the seventeenth century; Pietr de la Court, a mercantilist writer, even proposed the construction of a channel between Holland and the rest of the provinces, a new terra firma, in order to create a geographic unit similar to the Venetian one (De Vries and Van der Woude 1997); or a manufacturing nation, along the lines of England, once it had supplanted Holland as the leading trading nation. The Dutch model was the clearest example of a mercantilist policy; the English model was already shifting toward industry and progressing toward liberal ideas (Caton 1985, 837-38). The physiocrats' economic policies aimed to create a distinct model. In France, a larger country than either England or Holland, the importance of the agricultural sector favored the royaume agricole, the agricultural kingdom, a proposal that differed 
from those of the Dutch and English. The political organization was to be different too (Mirabeau and Quesnay [1757] 2000).

The third model to include agrarian techniques, in an indirect form, is Ricardo's corn model. The model is first presented in the Essay on Profits, but this essay analyzes only the origin of rent. In it, a state seems to be considered as a single farm. The variations of rent in the model under specific circumstances are better described in the chapter on the subject (chapter 11) in the Principles.

Ricardo's ideas are as follows:

The improvements which increase the productive powers of the land are such as the more skillful rotation of crops or the better choice of manure. These improvements absolutely enable us to obtain the same produce from a smaller quantity of land. If, by the introduction of a course of turnips, I can feed my sheep besides raising my corn, the land on which the sheep were before fed becomes unnecessary, and the same quantity of raw produce is raised by the employment of a less quantity of land. (1951-73, 1:80)

Later, Ricardo (1951-73, 1:80-81) speaks of the introduction of turnip husbandry, which defines more clearly the agronomic change involved. As a matter of fact, the new husbandry was centered on turnips (Timmer 1969).

Whether the turnips were to be introduced according to the Norfolk system, or rather following a particular application of Tull's idea, is a matter for debate. But if we remember that the Norfolk system had more adherents than Tull's theory, and that in Ricardo's time Tull's proposals were almost a century old, it seems fair to surmise that in Ricardo's model agriculture was based on intensive crop rotation as defined, in England, by the Norfolk system. Furthermore, as we have seen, Tull's idea was not the introduction of a course of turnips, but turnips as an alternative crop to corn. So Ricardo was describing a change from extensive corn production to crop rotation, probably along Norfolk lines: introducing turnips meant, perhaps, changing from a three-field system to a Norfolk system-a complete revolution, rather than a smooth movement along a continuous line. Ricardo only considered it as an intensification in the sense of more capital (seed) applied to land. In reality, the example he uses may be, in many respects, a change in technique, not just an intensification of factors applied. Only in this regard were agronomic practices important in Ricardo's model, but this importance was 
due to the special characteristics of agriculture that imposed a limit on a model in which there is one only product, corn. It is possible to imagine a different good, in abstract terms, but then the conclusions would have been different.

The level of abstraction used by Ricardo makes difficult any study of concrete problems. Among his speeches, there are some references to a proposal made by Owen in order to introduce spade husbandry in Ireland to solve unemployment problems (Ricardo 1951-73, 5:31). But there are no references to the agricultural system involved, and the speech just serves to elucidate Ricardo's views on machinery.

Finally, in his Isolated State ([1826] 1966), the last of the models to consider, von Thünen compares three systems: old agriculture, or the three-field system; new English intensive systems; and convertible husbandry in a modified form (Koppel), which was normal practice in northern Germany at the beginning of nineteenth century, besides other land uses such as forestry. Von Thünen's basic agronomic ideas were developed by his master, Thaer ([1809] 1831), who stressed the absolute advantages of the English (Norfolk) system, if "rational" criteria were adopted. Thaer's concept of rationality was an economic concept, for it meant more profits. (As a curious note, the term rational in the title of Thaer's book was translated in the French version as raisonnés, reasoned.) Von Thünen has normally been analyzed as an economist and not as an agronomist, although most of his work is dedicated to agronomic systems.

Von Thünen attended one of the seminars organized by Thaer at Celle, but he did not believe in the absolute advantage of the English system and began his research to prove the opposite. He introduced the distance variable in order to show that this advantage was merely relative, and that the intensity of cultivation will depend (if managed in a "rational" way) on distance from the market: "It is on the whole obvious that near the Town will be grown those products which are heavy or bulky in relation to their value and hence so expensive to transport that the more remote districts are unable to supply them. Here too, we will find the highly perishable products, which must be used very quickly. With increasing distance from the Town, the land will progressively be given up to products cheap to transport in relation to their value" (von Thünen [1826] 1966, 8).

In this case, the less intensive systems are located further away, so the corn-producing systems are, in terms of proximity to the market, as 
follows: crop alternation (English or Norfolk); improved (convertible, German style, or Koppelwirtschaft); and finally, the three-field system. In some cases, he studies the Belgian system (the Flanders one of the eighteenth century), but the results do not differ from the Norfolk system. But intensity is not the only variable result: forestry is not an intensive agrarian system (Roscher 1872), and it lies near the town for other reasons (transport costs).

When giving general results, the modern systems are called improved systems. In all cases, rents, as a part of the cost of production, are calculated according to the different products involved in the rotation, but in some cases, products have a physical form rather than a value (money form). The comparison of the systems leads to a general rule: "We conclude from this that improved farming enjoys no absolute advantage over the three field farming. The price of grain determines which of the two is the best in any given situation; with very low prices, the three field system is more profitable, with higher ones, the improved systems" (von Thünen [1826] 1966, 71).

Von Thünen thus represents a synthesis of the previous three agronomic systems, and even though he makes no reference to a single farm as the ideal state, his reasoning is similar to that of the other authors. Probably, he assimilated ideas from Cantillon, Quesnay, and specially Ricardo. For him, all the product may be measured in grain, even livestock production (von Thünen [1826] 1966, chap. 15).

The four models correspond to agricultural models of the economy and show the evolution of agronomy, an improving art that could offer high productivity: this is why economists used models of this kind to represent the economy as a whole. From the three-field system with natural pastures in Cantillon, through the three-field system with artificial pastures incorporated with La Salle's ideas, as in Quesnay; to the Ricardian steps toward a Norfolk system; and finally, to the dominance of the improved system (Koppel), in certain conditions, as von Thünen explained, we can see the evolution of farming systems through the evolution of economic models. The four models are based on agriculture only and, in this way, incorporated the best agrarian techniques; technical change was seen as a change in these techniques, not only as an intensification of labor and/or capital applied to land. It is true that the economists were able to obtain more general results of the agrarian models, and this gives to their models a theoretical value. Nevertheless, the origins of the models were basically agrarian, and even von Thünen was 
as much an able agronomist as an economist, something that cannot be said of other theorists. As for Ricardo, his later models were based on a partially industrial economy with machinery incorporated, in which industry was the leading sector. But in qualitative terms, agriculture still marked the basic fact, the rate of profit.

\section{Conclusions}

The history of political economy tends to link its great moments, from Smith on, with the birth of an industrial society, characterized by the division of labor, and some of its basic problems with machinery, or, in another form, with fixed capital in the form of industrial machinery. Ricardo's chapter "On Machinery" is one of the landmarks in its development (Berg 1980). Historians of economic thought tend to accept this view, since our society is industrial; we tend to believe that we must trace the economic interpretation of our society back to the times of its incipient industrialization, and not beyond. In this view, the modifications of the agrarian world, and its interpretations, are considered unimportant.

But we have seen that highly significant concepts and models of our science appeared as interpretations of agrarian changes, not industrial changes. In these changes, new techniques played an important role. Agricultural techniques, during the eighteenth century, attracted the attention of the political economists. Some historians of economic thought have pointed to the relation between the birth of political economy and agrarian capitalism (McNally 1988), but the techniques that helped agrarian capitalism have been largely neglected, despite the fact that these techniques were among its most important components.

We have seen that the relation between agronomy and political economy gave rise to a fruitful transmission of ideas and that some important concepts in political economy were influenced by agrarian techniques and by the interpretation of their results. This transmission included the concepts of surplus, or produit net, the law of decreasing returns, and the different conceptions of technical change. But more importantly, agronomic techniques and agrarian models of production provided the first models of economic production, even at a time when industry was becoming the main focus of economic activity. It may be said that this was merely because, during the period of classical economics, economies were mainly, if not entirely, agricultural. But probably the real reason 
is that the special characteristics of agriculture make it a sector in which certain economic tools and concepts are particularly well understood.

\section{References}

Abel, W. 1980. Agricultural Fluctuations in Europe. London: Methuen.

Ambrosoli, M. 1992. Scienciati, contadini e propietari. Turin: Einaudi.

Amouretti, M. C., and F. Sigaut. 1998. Traditions agronomiques européennes. Paris: CTHS.

Anderson, J. [1777] 1966. Inquiry into the Nature of the Corn Laws. In A Select Collection of Scarce and Valuable Tracts, edited by J. R. McCulloch, 321-25. New York: Kelley.

Argemí, L. 1994. Quesnay, agronome. Paper presented at the Colloque François Quesnay, Versailles 1994.

Aspromourgos, T. 1996. On the Origin of Classical Economics. London: Routledge.

Berg, M. 1980. The Machinery Question and the Making of Political Economy. Cambridge: Cambridge University Press.

Bidet, M. [1759] 1788. Trattato sopra la coltivazione delle viti. Naples: La Nuova Societá Letteraria.

Blaug, M. 1985. Economic Theory in Retrospect. Cambridge: Cambridge University Press.

Boserup, E. 1967. The Conditions of Agricultural Growth. London: Allen and Unwin.

Bourde, André J. 1967. Agronomie et agronomes en France au XVIIIème siècle. Paris: SEVPEN.

Boussingault, J. B. 1851. Économie rurale. Paris: Bechet Jeune.

Braudel, F. 1979. Civilisation matérielle, économie et capitalisme. Paris: Armand Colin.

Brewer, A. 1992. Richard Cantillon. London: Routledge.

Brewster, J. 1950. The Machine Process in Agriculture and Industry. Journal of Farm Economics 32:69-81.

Butré, C. 1781. Loix naturelles de l'agriculture et de l'ordre social. Neuchatel: Matre.

Candolle, A. P. de. 1832. Physiologie végétale. Paris: Bechet Jeune.

Cantillon, R. [1755] 1964. Essai sur la nature du commerce en géneral. New York: Kelley.

_ [1755] 1997. Essai sur la nature du commerce en général. Paris: INED.

Caton, H. 1985. The Pre-industrial Economics of Adam Smith. Economic History Review 45:833-53.

Chaptal, Conde [Jean Antoine]. [1823] 1829. Química aplicada a la agricultura. Barcelona: Jose Rubio.

_. [1819] 1993. De l'industrie française. Paris: Imprimerie Natinale.

Chorley, G. 1981. Nitrogen, Legumes, and Crop Productivity. Economic History Review 34:71-93. 
Cohen, M. N. 1978. The Food Crisis in Prehistory: Overpopulation and Origins of Agriculture. New Haven, Conn.: Yale University Press.

Dagognet, F. 1973. Des révolutions vertes. Herman: Paris.

De Vries, J., and K. Van der Woude. 1997. The First Modern Economy. Cambridge: Cambridge University Press.

Dewey, C. 1974. The Rehabilitation of the Peasant Proprietor in Nineteenth-Century Economic Theory. HOPE 6.1:17-47.

Duhamel de Monceau, H. L. 1750. Traité de la culture des terres suivant les principes de Mns. Tull, anglois. 6 vols. Paris: Hyppolite Louis Guerin.

- 1764. Réflexions sur la police des grains en France et en Angleterre. n.p.

— . [1762] 1813. Elementos teórico-prácticos de agricultura. Madrid: Josef del Collado.

Du Pont de Nemours, P. S. [1768] 1992. De l'origine et des progrès d'une science nouvelle. Catania, Italy: CUECM.

Estienne, C., and J. Liebaut. 1586. L'agriculture et Maison Rustique. Lyon: Jacques du Puys.

Evelyn, J. 1706. Sylva, or a Discourse on Forest-Trees. Terra. A Discourse on Earth. Pomona, or an appendix concerning Fruit-Trees. Acetaria, a Discourse on Sallets. London: Scott.

François Quesnay et la physiocratie. 1958. Paris: INED.

Georgescu-Roegen, N. 1969. Process in Farming versus Process in Manufacturing: A Problem of Balanced Growth. In Economic Problems of Agriculture in Industrial Societies, edited by U. Papi and C. Nunn, 497-528. New York: Wiley.

Hayami, Y., and V. Ruttan. 1971. Agricultural Development. Baltimore: Johns Hopkins Press.

Hecht, J. 1958. La vie de François Quesnay. In François Quesnay et la physiocratie, 211-94. Paris: INED.

La Salle d'Etang, M. de. 1762. Prairies artificielles. Paris: Desaint.

- 1764. Manuel d'agriculture pour le laboreur, pour le propriétaire, et pour le gouvernement. Paris: Lottin et Dessain.

Levy, H. 1966. Large and Small Holdings. London: Frank Cass.

Liebig, J. n.d. Les lois naturelles de l'agriculture. Brussels: Rodez.

. [1858] 1880. Lettres sur l'agriculture moderne. Paris: Libraire Agricole de la Maison Rustique.

Linnaeus, C. [1758] 1972. L'équilibre de la nature. Paris: Vrin.

[Mallet, R. X.]. 1780. Éléments d'agriculture. Paris: Meurant.

Malthus, T. R. [1815] 1969. An Inquiry on the Nature and Progress of Rent. New York: Greenwood.

— [1803] 1989. An Essay on the Principle of Population. Cambridge: Cambridge University Press.

Marcandier, M. 1758. Traité du chanvre. Paris: Nyon.

Marshall, T. H. 1929. Jethro Tull and the New Husbandry of the Eighteenth Century. Economic History Review 2.1:41-60. 
Martínez Alier, J. 1984. L'ecologisme i l'ecologia. Barcelona: Edicions 62.

Maupin, M. 1780. L'art de la vigne. Paris: Musier.

McNally, D. 1988. Political Economy and the Rise of Capitalism: A Reinterpretation. Berkeley: University of California Press.

Mill, J. S. [1848] 1965. Principles of Political Economy. Toronto: University of Toronto Press.

Mirabeau, Victor Riquetti, Marquis de. 1756. L'ami des hommes. Avignon.

Mirabeau, M. de, and F. Quesnay. [1757] 2000. Traité de la monarchie. Paris: L'Harmattan.

Mirowski, P. 1989. More Heat than Light. Cambridge: Cambridge University Press.

Mulliez, J. 1979. Du blé, mal nécessaire. Revue d'histoire moderne et contemporaine 26:3-47.

Murphy, A. 1986. Richard Cantillon: Entrepreneur and Economist. Oxford: Clarendon.

Nell, E. 1984. Historia y teoría económica. Barcelona: Crítica.

Newell, J. 1973. The Agricultural Revolution in Nineteenth Century France. Journal of Economic History 33:697-730.

Nõu, J. 1967. The Development of Agricultural Economics in Europe. Uppsala: Almqvist \& Wicksell.

Patullo, Henri. [1758] 1774. Discurso sobre el mejoramiento de los terrenos. Madrid: Real Compañia de Impresores y Libreros del Reino.

Perelman, M. 1984. Classical Political Economy. London: Rowman.

Perrot, J. C. 1992. Une histoire intellectuelle de l'économie politique. Paris: École des Hautes Études Sociales.

Re, P. Y. 1802. Elementi di agricoltura. Venice: Pezzana.

Ricardo, D. 1951-73. The Works and Correspondence of David Ricardo. Edited by Piero Sraffa, with the collaboration of M. H. Dobb. 11 vols. Cambridge: Cambridge University Press.

Roscher, W. 1872. Recherches sur divers sujets d'économie politique. Paris: Guillaumin.

- [1859] 1876. Economia dell'agricoltura. Vol. 1 of Biblioteca dell'economista. Turin: Unione Tipografico-editrice.

Rose, L. 1769. Le bon fermier, ou l'ami des laboreurs. Lille: J. B. Henry.

Rozier, A. 1787. Cours complet d'agriculture ou dictionnaire universel d'agriculture. Paris: Rue et Hotel Serpente

Saussure, T. de. 1804. Recherches chimiques sur les végétaux. Paris: Delain.

Say, J. B. [1803] 1972. Traité d'économie politique. Paris: Calmann-Levy.

Schabas, M. 1992. Breaking Away: History of Economics as History of Science. HOPE 24.1:187-203.

Schaffer, S. 1999. Enlightened Automata. In The Sciences in Enlightened Europe, edited by W. Clark, J. Golinski, and S. Schaffer, 126-65. Chicago: University of Chicago Press. 
Schultz, T. W. 1951. The Declining Importance of Agricultural Land. Economic Journal 61:725-40.

Schumpeter, J. A. 1954. History of Economic Analysis. New York: Oxford University Press.

Sigaut, F. 1998. Entre practiques raisonnées et science efficace. In Traditions agronomiques européennes. Paris: CTHS.

Simonde de Sismondi, J. C. L. [1819] 1971. Nouveaux principes d'économie politique. Paris: Calman Levy.

Sinclair, J. 1821. Code of Agriculture. London: Sherwood.

Slicher van Bath, G. H. 1974. Historia agraria de Europa occidental. Barcelona: Península.

Smith, A. [1776] 1976. An Inquiry into the Nature and Causes of the Wealth of Nations. Oxford: Clarendon.

Soboul, A., G. Lemarchand, and M. Fogel. 1977. Le siècle des lumières. Paris: PUF.

Spary, E. 1996. Natural, Political, and Bodily Economies. In Cultures of Natural History, edited by N. Jardine, J. A. Seacord, and C. A. Spary, 178-96. Cambridge: Cambridge University Press.

1999. The "Nature" of Enlightenment. In The Sciences in Enlightened Europe, edited by W. Clark, J. Golinski, and S. Schaffer, 272-304. Chicago: University of Chicago Press.

Steiner, P. 1998. La "science nouvelle" de l'économie politique. Paris: PUF.

Sumpsi, J. M. 1978. Estudio de la transformación del tercio al año y vez en la campiña de Andalucia. Agricultura y sociedad 31-70.

Thaer, A. [1809] 1831. Principes raisonnés d'agriculture. Paris: Cherbuliez.

Timmer, P. 1969. The Turnip, the New Husbandry, and the Agricultural Revolution. Quarterly Journal of Economics 83:375-95.

Tribe, K. 1978. Land, Labor, and Economic Discourse. London: Routledge.

Tull, J. [1731] 1751. The horse-hoeing husbandry. London: Millar.

Turgot, A. R. J. [1767] 1997. Formation et distribution de richesses. Paris: Flammarion.

Usher, A. P. 1923. Soil Fertility, Soil Exhaustion, and Their Historical Significance. Quarterly Journal of Economics 37:385-411.

von Thünen, J. H. [1826] 1851. Recherches sur l'influence que le prix des grains, la richesse du sol et les impôts exercent sur les systèmes de culture. Paris: Guillaumin.

— . [1826] 1966. The Isolated State. London: Pergamon.

Wallerius, J. G. 1774. L'agriculture reduite à ses vrais principes. Paris: Lacombe.

Weulersse, G. 1968. Le mouvement physiocratique en France. Paris: Mouton.

White, Lynn T., Jr. 1962. Medieval Technology and Social Change. Oxford: Oxford University Press.

Wood, N. 1984. John Locke and Agrarian Capitalism. Berkeley: University of California Press.

Young, A. [1773] 1967. Political Arithmetic. New York: Kelley. 